\title{
Basic Notion of Infrastructure Asset Management What UNIID should do ?
}

\author{
Hitapriya Suprayitno ${ }^{\text {a* }} \&$ Ria Asih Aryani Soemitro ${ }^{a}$ \\ ${ }^{a}$ Civil Engineering Department., Institut Teknologi Sepuluh Nopember, ITS Campuss Sukolilo, Surabaya 60111, Indonesia \\ Magister Program on Infrastructure Asset Management
}

\begin{abstract}
Infrastructure Asset Management is important. In the developed countries the IAM has been implemented largely and deeply; and its give significant positive result. In Indonesia, the IAM is not yet popular, it is just recently started. The IAM need to be implemented more and better in Indonesia. Three main questions concerning UNIID and the IAM : what the IAM is, how the IAM Practices are and what UNIID should do. The main program to be realized is a creation of IAM Group in UNIID. The main duty of this group is participating in developing more and better IAM Practice in Indonesia.
\end{abstract}

Keywords: infrastructure asset management.

\section{Introduction}

Infrastructure Asset Management (IAM) is very important. In Indonesia the IAM is not yet popular, it is relatively just started to be known and implemented. Otherwise, in the developed countries, the IAM has been implemented largely and deeply. IAM Associations have been established and function quite well, with a large membership, regular acitivities - either professional and scientific, and competency certification. ISO standard has been issued for IAM. This implementation give a positive result.

The IAM need to be implemented in Indonesia. In Indonesia, concious or unconcious, Asset Management in some extent and in certain fields has been implemented, either deliberately or not. So the objective of IAM Development in Indonesia must be as follow : enlarging, strengthening the IAM Practice.

University Network for Indonesian Infrastructure Development (UNIID) was just established recently. One of the focus of the UNIID is the IAM. Therefore, it is important to define : What the UNIID shoul do for the IAM.

For this first step, for UNIID, it is important to try to define the IAM Notion, to observe the IAM practice, and to formulate what UNIID shoul do in strenghten the IAM Practice in Indonesia.

\section{Infrastructure Asset Management Notion}

\section{Asset Management}

Asset Management lexic is used quite a lot now in Indonesia and the world. Asset can be defined as valuable property owned by someone or an instition. The valuable asset it self can be a physical or non physical object. Example of those are : house, car, land, etc for the physical object and knowledge, finance, etc for the non physical object. So Asset Management can be defined as knowledges and actions to manage the valuable asset.

Financial Institutions in Indonesia use a lot this term to indicate portofolio management. A Financial Asset Management is then a financial institution which manage the clients financial asset by using financial product, such as : share, obligation, future trade, and strong foreign valuta and others. Its objective is to maximize gain with acceptable risk.

\section{Infrastructure}

Infrastructure can be defined as all kind of man made building. They vary in sectors : energy, transportation water resources, etc. Thus the vary strongly in function, form, structure, operation, etc. This will be dicussed deeper later on. Examples of several infrastructure types are presented in Figure 1 as follow. 

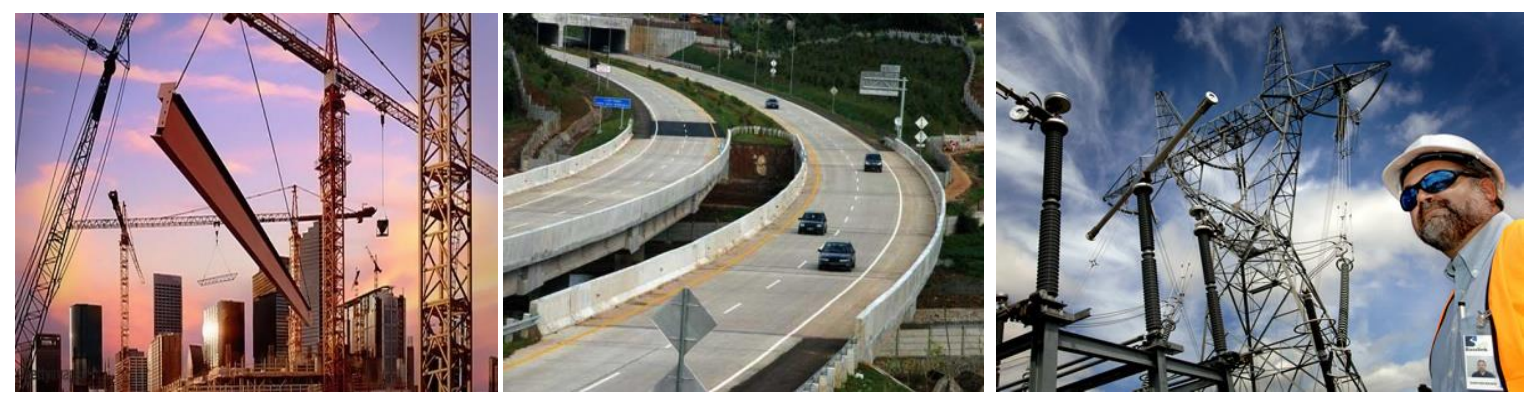

Fig. 1. Example of Various Infrastuctures

\section{Infrastructure Asset Management}

Based on the Asset Management principal mentioned above, the Infrastructure Asset Management (IAM) can be simply defined as knowledges and actions in Managing Infrastructure. The infrastructures itself exist in various type and form. In certain cases, it is called as Facility Management.

Technically the IAM is defined as managing the infrastructures in its whole life cycle. The main objective is assuring the minimum infrastructure performance, with maximimizing the benefit while minimizing the cost, together with managing infrastructure development due to its environment development, assuring sustainability in three main aspects : social, economy and environmental and with managing every risk possible.

\section{Infrastructure Life Cycle}

Since the IAM means managing the infrastructure in its whole life cycle, defining well the infrastructure life cycle is very important in IAM. Each steps of life cycle has different nature, therefore different cycle objective and different management technic. Different attempt in defining the infrastructure life cycle gave different formulation of life cycle staging.

After studying the different idea of life cycle staging based on different attempts and the nature of differents stages, the most appropriate staging for IAM is as follow : Idea, Planning, Design, Construction, Sertification, Administration, Operation, Maintenance, Disposal. Difference infrastructure may experience different characteristics in its life cycle. The Infrastructure Life Cycle Model is presented in Figure 2 below.

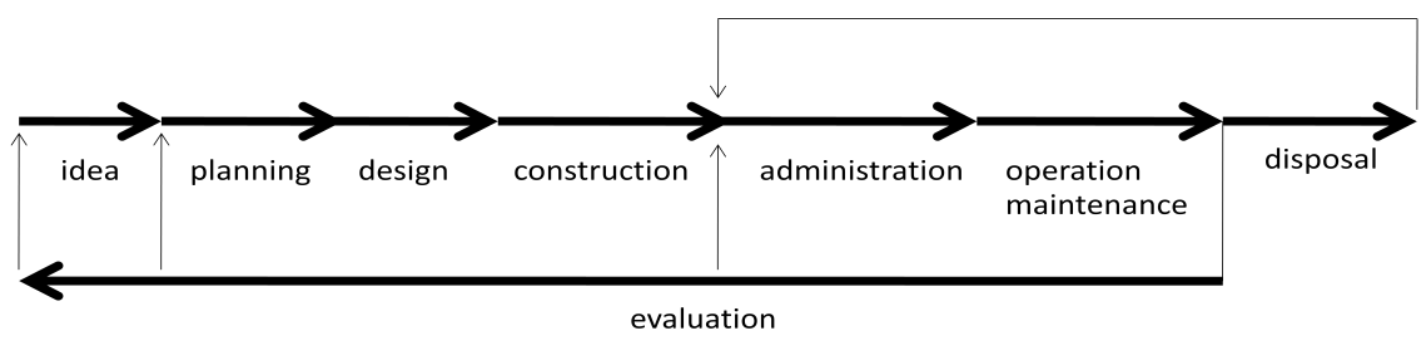

Fig. 2. Infrastructure Life Cycle Model

\section{IAM Basic Knowledge}

The IAM Basic Knowledge must be devided into two main parts : infrastructure management part and organization management part. The classic organization management main knowledge can be mentioned, among others, as follows : principal of management, human resources management, financial management, marketing management, project management, decisin making, etc. The infrastructure management main knowledge can be mentioned among others, as follows : principal of infrastructure asset management, basic infrastructure engineering, infrastructure economics, infrastructure policy, principal of infrastructure planning, infrastructure information system, maintenance management, operation management, infrastructure certification \& administration, project management, decision making, strategic management, risk management, etc. Illustration of these basic knowledge is presented in Figure 3 below. 


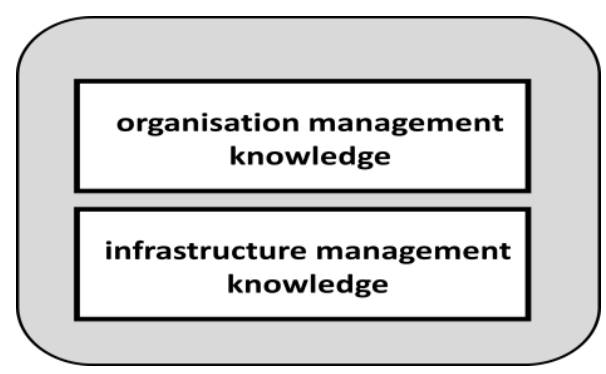

Fig. 3. Infrastructure Asset Management Knowledge

\section{Important Infrastructure Characteristics}

It must be noted that different infrastructure in general have different main characteristics. The main characteristics must be considered are its : function, architecture, supply-demand, network, minimum performance standard, economic, etc. Different characteristics resulting in different asset management problem and solution modes.

\section{IAM Practice}

It is vewry important to observe the IAM current practice in order to formulate what UNIID should do in Infrastructure Asset Management.The observation was made in developed country and Indonesia. IAM Practice observation was made for practices in government, business, education and the existence of IAM association..

\section{Practice in Developed Country}

IAM as defined above has been implemented or practiced vastly and deeply in the developed countries. Several examples can be mentioned as follows. The establishment of IAM Standard : ISO 55000. Example of IAM Practice in Government can be found everywhere, an example for instance : Queensland State Asset Management. Practically all big companies are already practicing the IAM : Boeing, Airbus, British Railway, SNCF, etc. Example of IAM Practice in Academic Institution : the existence of Infrastructure Management Group, Institute of Construction and Infrastructeure Management, ETH (Eidgenossiche Technische Hochschul), Zurich, Switzerland; establishment of IAM Association in QUT, Brisbane, Australia; etc. Examples in terms of IAM Association : IAM Association in Great Britain, IFRAMI : Institut Francais d'Asset Management Industriel et Infrastructure in France. Both associations have good and deep regular acitivities : seminars, workshop, certification.

\section{Practice Indonesia}

Certainly, infrastructure management has been practiced in Indonesia since long time ago. The infrastructure are managed in a certain way, and it is not always or even not at all in corcodance with the IAM notion mentioned above. Recently, the the IAM has been started to be implemented. Several examples of indonesian practice are mentioned as follows. Ministry of Public Works and Public Housing has a section called Biro Barang Milik Negara and organized a Master Degree in IAM in cooperation with ITS. Ministry of Finance, for example, has just established : LMAN - Lembaga Manajemen Aset Nasional to cope the land acquisition problem for infrastructure development. For bussines world it can be mentioned that Indonesia Power and Indonesian Cement have implement the ISO 55000. In academy sector, it can be noted that : ITS organized Master Program and IAM Allumnee Association, the establishment of UNIID.

\section{IAM Standard}

Last things very important to be written here is the IAM Regulation and Standard. A part from the different infrastructure regulation and technical manual, for Indonesia there are three main regulations on IAM which must be refered, as follows.

- Peraturan Pemerintah No 17 Tahun 2014 tentang Pengelolaan Barang Milik Negara.

- Peraturan Menteri Dalam Negeri No 19 Tahun 2016 tentang Pengelolaan Barang Milik Daerah.

- $\quad$ ISO 55000 series in Asset Management.

\section{What UNIID should do ?}

The IAM has been implemented largely in developed countries and give positive result. So it is an obligation for UNIID to promote the IAM Implementation. The main objective must be to strengthen the IAM Implementation in government, bussiness and academic and to develop the IAM Knowledge. The main important tasks to be executed thus are : socialization, workshop, association, journal. So, UNIID has to establish The IAM Group inisde the UNIID Organozation. 


\section{Conclusions}

Several conclusions can be drawned as follows. The basic notion of IAM has been presented, several example of IAM Practice have been presented also and to create IAM Group in UNIID.

\section{References}

Use the "Insert Citation" button to add citations to this document. 